Man and Nature

L'homme et la nature

\title{
"Cher et illustre Roscius" David Garricks Influence on the Dramatic Theories of Diderot
}

\section{F. M. Wilkshire}

Volume 6, 1987

URI : https://id.erudit.org/iderudit/1011867ar

DOI : https://doi.org/10.7202/1011867ar

Aller au sommaire du numéro

Éditeur(s)

Canadian Society for Eighteenth-Century Studies / Société canadienne d'étude du dix-huitième siècle

ISSN

0824-3298 (imprimé)

1927-8810 (numérique)

Découvrir la revue

Citer cet article

Wilkshire, F. M. (1987). "Cher et illustre Roscius" David Garricks Influence on the Dramatic Theories of Diderot. Man and Nature / L'homme et la nature, 6, 21-34. https://doi.org/10.7202/1011867ar

Copyright (C Canadian Society for Eighteenth-Century Studies / Sociéte canadienne d'étude du dix-huitième siècle, 1987
Ce document est protégé par la loi sur le droit d'auteur. L'utilisation des services d'Érudit (y compris la reproduction) est assujettie à sa politique d'utilisation que vous pouvez consulter en ligne.

https://apropos.erudit.org/fr/usagers/politique-dutilisation/ 


\section{"CHER ET ILLUSTRE ROSCIUS" DAVID GARRICK'S INFLUENCE ON THE DRAMATIC THEORIES OF DIDEROT}

It is almost certain that Diderot and Garrick did not meet during the latter's first visit to Paris in 1751 . The actor-manager of Drury Lane was in the early stages of his renowned career and it seems that there was a professional reason for the trip. Garrick was a personal friend of Jean Monnet, director of the Opéra-Comique, and was interested in recruiting dancers for Drury Lane. However, in the diary he kept during his stay, Garrick gives no indication of this and writes only of sight-seeing, theatre-going and occasional dinner invitations from members of the English colony in Paris. His social contacts seem to have been limited to this group and Monnet's theatrical circle; nowhere is there mention of the "philosophes". ${ }^{1}$ However, Colle's journal registers the actor's presence in the city and, in July 1751, gives an enthusiastic account of Garrick's performance of the dagger-scene from Macbeth at a private gathering:

... il [Garrick] nous joua une scène d'une tragédie de Shakespeare, dans laquelle nous aperçumes facilement que ce n'est point à tort que cet homme jouit d'une aussi grande réputation. Il nous esquissa la scène où Macbeth croit voir un poignard en l'air, qui le conduit à la chambre où il doit assassiner le roi. Il nous inspira la terreur ... Ce qu'il nous joua était une espèce de pantomime tragique, et par ce seul morceau je ne craindrais point d'assurer que ce comédien est excellent dans son art ... ${ }^{2}$ 
The impact of such performances served to firmly establish Garrick's reputation in Parisian literary circles and caused him to become something of a legend so that seven years later, Diderot refers to the duc de Duras' account of a similar and equally impressive piece of mime performed during this first visit.

The advent of war between England and France prevented a return visit until 1763 when Garrick and his wife undertook the Grand tour, passing briefly through Paris on the outward journey and returning for a lengthy stay in the winter of 1765 . By this time Garrick's reputation was established throughout Europe. Sterne, who had ventured across the Channel in 1762 before the formal ending of hostilities, gives his friend an indication of this reputation when he writes from Paris in April of that year:

You are much talked of here, and much expected, as soon as the peace will let you ... These last two days you have happened to engross the whole conversation of two great houses where I was at dinner. ${ }^{3}$

There can be little doubt that one of these was the salon of the baron $\mathrm{d}$ 'Holbach where Sterne speaks of being welcomed and entertained. It would be surprising if Diderot had not been present at such a gathering and the particular subject for discussion, quoted by Sterne, "that one and the same man should possess such tragic and comic powers" 4 was one that both Grimm and Diderot referred to at a later date.

When Garrick eventually arrived in Paris in September 1763, his personal reputation and the current Anglomania combined to make him the darling of literary and philosophical circles. The actor, never averse to flattery, and having left England during a temporary lull in his popularity, savoured the adulation and responded with salon performances displaying his amazing talent and versatility. One of these, at which Diderot was most likely present, is described by Garrick in a letter to George Colman, his associate:

I was in Spirits and so was the Clairon, who sup'd with us at Mr. Neville's - She got up to set me a going and spoke something in Racine's Athalie most charmingly - upon which I gave them the Dagger Scene from Macbeth, the Curse in Lear, and the falling asleep in Sr John Brute, the consequence of which is, that I am now star'd at the Playhouse, and talked of by Gentle and Simple - the Nobles and the Literati have made so much of me that I am quite ashamed of opening my Heart Ev'n to you. ${ }^{5}$

It was on his return from Italy, that Garrick, obliged to spend the 
winter of 1765 convalescing in Paris, cemented his friendships with Diderot and other members of the d'Holbach circle. He also frequented the salon of the fermier-général Pelletier enjoying the company of Crébillon, Collé and Saurin but it was "chez les philosophes" that he appears to have felt most at ease.

In February 1765, he writes to Colman: "We had a fine laugh at Baron d'Albach's (sic) (where you din'd once) about the wicked company I keep; I am always with that set."6 Grimm, in his glowing tribute to Garrick in the Correspondance littéraire for July 1765 defines the association more formally:

Il [Garrick] serait ingrat s'il ne regrettait un peu la France, où il a reçu l'accueil le plus distingué, mais où il s'est borné de préférence au commerce des philosophes, dont il a emporté les regrets et dont il chérit à son tour le ton, les moeurs et les lumiéres ... le Roscius anglais a été de la religion et de l'église du petit troupeau. ${ }^{7}$

The image of the "philosophes"' religion recurs in Diderot's only existing letter to Garrick, written to commend for English adaptation the Honnête Criminel by Fenouillet de Falbaire. The letter ends with a friendly reminder of dinners at the baron's so-called "synagogue" in the rue Royale-St. Roch:

Adieu, Monsieur et très aimable, souvenez-vous de temps en temps de la synagogue de la rue Royale et du petit sanctuaire de la rue Neuve-des-PetitsChamps; on y fait souvent commémoration de vous le verre en main, et l'on vous y boit en bourgogne, en champagne, en malaga, en toutes couleurs, en tout pays. Je suis, comme vous le savez, votre admirateur, et je serais bien fâché que vous ne me comptassiez pas au nombre de vos amis. ${ }^{8}$

Garrick demonstrated his friendship and interest by becoming one of the first English subscribers to the Encyclopédie. Grimm, writing in February 1766 to "mon cher et illustre Roscius" refers to "le philosophe Diderot, qui vous aime autant que moi" and adds: "C'est lui qui m'a donné vôtre souscription, et qui m'a prié de vous faire expédier votre exemplaire."9 Garrick, in regular correspondence with d'Holbach, Grimm, Morellet and Suard sends frequent greetings to the "philosophe" and on his library copy of Lettre sur les Aveugles, now in the British Museum, he has inscribed: "Written by my Friend Diderot."

If existing evidence of personal correspondence between the two men is slim, the references to Garrick in Diderot's writings on dramatic theory attest to the latter's immense admiration for the English actor. Gar- 
rick, more than any French actor or actress of the period, was the incarnation of Diderot's ideal. Just as he had singled out the English domestic tragedies of Lillo and Moore as models for the new "tragédie bourgeoise" so Garrick became the model for his theories on the art of acting - theories which evolved significantly between 1757 and 1770 .

In his initial attempts at dramatic renewal, Diderot makes a strong plea for the use of mime and gesture in the interests of realism and as a reaction to the outmoded conventions of the declamatory style employed by French tragedians. Voltaire, in his earlier and less radical attempts at reform had referred to French tragedies as "plutôt des conversations qu'elles ne sont la représentation d'un événement." 10 In Diderot's first major treatise on the theatre, the Entretiens sur le Fils Naturel (1757), Dorval, the writer's mouth-piece, refers to the successful use of mime in that play and adds:

Nous parlons trop dans nos drames; et, conséquemment nos acteurs n'y jouent pas assez ... Quel effet cet art, (la pantomime), joint au discours, ne produirait-il pas? Pourquoi avons-nous séparé ce que la nature a joint?"11

The Discours de la Poésie dramatique written a year later in conjunction with Le Père de Famille stresses the importance of an art lacking in French classical tragedy:

J'ai dit que la pantomime est une portion du drame ... et que le geste doit s'écrire souvent à la place du discours. J'ajoute qu'il y a des scènes entières où il est infiniment plus naturel aux personnages de se mouvoir que de parler et je vais le prouver. ${ }^{12}$

True to his word, Diderot, the dramatist, fills his plays with elaborate stage directions. His characters sigh deeply, put their heads in their hands, bite their lips, beat their breasts and fall on their knees. Their speeches are punctuated by sighs or long silences. A typical example occurs in Act II, Scene V of Le Fils naturel where Dorval, in one stage direction, "Se renverse dans un fauteuil ... s'abîme dans la rêverie ... jette ses mots par intervalles." Small wonder that Diderot found the "comédiens français" trained in the declamatory style, unreceptive, if not hostile, to the acting requirements of his plays.

Nor is it surprising that Diderot should have received reports of Garrick's innovative acting with enthusiastic approval. Garrick, himself, with his insistence on the 'natural' style of speech and his use of action, gesture and facial expression, was reacting to the neo-classical style of predecessors such as Quin. A contemporary, Richard Cum- 
berland, quoted by Cecil Price in his book on acting in the age of Garrick, highlights the contrast in a description of the two actors in The Fair Penitent by Rowe. Quin's pompous and monotonous declaiming is followed by the appearance of Garrick as Lothario "alive in every muscle, and in every gesture" ... and, adds Cumberland, "it seemed as if a whole century had been stept over in the transition of a single scene."13

The contrast with his French counterparts must have been at least as striking. Mlle Clairon had made some attempts to alter her style in 1755 with her performance in Voltaire's L'Orphelin de la Chine. After seeing her in that role, Collé notes that: "... elle se défait peu à peu de sa déclamation et marche à grands pas au jeu naturel."14 But she was an exception. It should be remembered that Clairon had witnessed Garrick's acting in 1751 and had been impressed and, no doubt, influenced by it. A contemporary comment by John Hill concerning Le Kain, the principle tragic actor of the period, indicates that his technique was still very much a traditional one depending almost totally for dramatic effect on the modulation of the voice:

... he has less action than any of the English players: He will stand in his place on the stage, with his arms genteely disposed, and without once stirring hand or foot, go thro' a scene of the greatest variety. ${ }^{15}$

For Diderot and his contemporaries, the contrast between Garrick and actors such as Le Kain must have been particularly striking because the English actor chose his salon extracts with a view to maximum pantomimical effect to offset his audience's limited (or non-existent) command of the English language. Thus, with exaggerated emphasis on action, gesture and facial expression in the dagger scene from Macbeth, the ghost scene from Hamlet, the curse from Lear, Garrick was able to convey the dramatic power of Shakespeare to audiences for the most part unacquainted with his work except through the woefully inadequate translation of the period.

There are numerous contemporary comments on Garrick's acting techniques, not all of them favourable. From an admirer, the German Lichtenberg, we have a description of the ghost scene from Hamlet:

Garrick turns abruptly round, and, at the same moment, totters backward two or three steps, his legs giving way beneath him; his hat falls on the ground; his arms, especially the left, are almost fully spread, the hand on a level with his head, the right arm bent with the hand hanging down, the fingers wide apart, the mouth open ... his features expressed such horror 
that I felt a shudder run through and through me, even before he began to speak; when at length he does speak, he does not take breath first but uses the end of a respiration, and it is in a trembling voice that he says, 'Angels and ministers of grace, defend us'. ${ }^{16}$

Negative criticisms were not lacking. The following, by Theophilus Cibber, though undoubtedly biased, gives an indication of the dangers of caricature in such a style. He describes Garrick's "over-fondness for extravagant Attitudes, frequently affected Starts, Convulsive Twitchings, Jerkings of the Body, sprawling of the Fingers, flapping of the Breast and Pockets. A set of mechanical motions in constant use - the Caricatures of gesture suggested by pert Vivacity." As to Garrick's speech, Cibber attacks "his pantomimical manner of acting every word in a sentence; his forc'd Conceits, his wilful Neglect of Harmony, even where the Round Period of a well express'd Noble Sentiment demands a graceful Cadence in the delivery."17 To a less hostile critic, Garrick wrote a lengthy defense of his technique in delivering Shakespearean speeches, justifying the "Unnatural Pauses" and "acting of every word in a Sentence" with a psychological interpretation of the significance of the lines. ${ }^{18}$

If one juxtaposes these descriptions of Garrick's acting with one of Diderot's impassioned pleas for pantomime, one is immediately aware of the affinity between what Diderot was advocating in his theoretical works and what Garrick was actually performing for his public. Eight years before Diderot's personal experience of Garrick's acting, he writes:

Mais ce qui émeut toujours, ce sont des cris, des mots inarticulés, des voix rompues, quelques monosyllabes qui s'échappent par intervalles, je ne sais quel murmure dans la gorge, entre les dents ... La voix, le ton, le geste, l'action, voilà ce qui appartient à l'acteur. ${ }^{19}$

The first specific mention of Garrick in Diderot's writings on the theatre comes in the Réponse à une lettre de Mme Riccoboni (1758). Diderot's reply was elicited by a letter of criticism from the spirited ex-actress turned novelist (and, incidentally, subsequent close friend and frequent correspondent of Garrick). She had taken exception to Diderot's statements on acting in the Discours de la Poésie dramatique her objection being that, not being an actor himself, he was unqualified to pronounce on such matters and did not know "les petits détails d'un art qui comme tous les autres a sa main-d'oeuvre." ${ }^{\prime 20}$ She 
argues that actors are obliged to observe certain techniques because of the exigences of the stage. Diderot's answer is unequivocal: in that case, change the stage! To one of her objections, he retorts with an attack on the restriction of the "jeu déclamatoire" which, he argues, has reduced actors to the level of mere puppets: "Vous vous résoudrez donc toute votre vie à n'être que des mannequins?"21 He continues with the duc de Duras' account of one of Garrick's salon performances in 1751 to demonstrate the powerful effects of mime:

Vous connaissez de réputation un acteur anglais, appelé Garrick; on parlait un jour, en sa présence, de la pantomime, et il soutenait que, même séparée du discours, il n'y avait aucun effet qu'on n'en pût attendre. On le contredit, il s'échauffe; poussé à bout, il dit à ses contradicteurs en prenant un coussin: "Messieurs, je suis le père de cet enfant." Ensuite il ouvre une fenêtre, il prend son coussin, il le saute et le baise, il le caresse et se met à imiter toute la niaiserie d'un père qui s'amuse avec son enfant; mais il vint un instant où le coussin ou plutôt l'enfant lui échappa des mains et tomba par la fenêtre. Alors Garrick se mit à pantomimer le désespoir du père. Les spectateurs en conçurent des mouvements de consternation et de frayeur si violents que la plupart se retirèrent. ${ }^{22}$

Diderot uses the same example, with slight modifications, in a letter of advice written to a young actress, Mlle Jodin, in August 1765:

Je voudrais bien que vous eussiez vu Garrick jouer le rôle d'un père qui a laissé tomber son enfant dans un puits. Il n'y a point de maximes que nos poètes aient plus oubliées que celle qui dit que les grandes douleurs sont muettes. ${ }^{23}$

The window has become a well but the force of the mute image remains and it is probable that, by this time, Diderot had himself experienced this piece of pantomime.

Garrick's eager promotion of Shakespeare could not fail to meet with Diderot's approval. In fact, in the Shakespeare-Racine controversy, the actor's salon performances, with their powerful dramatic impact, were welcome propaganda for the pro-Shakespeare "philosophe" camp. Diderot goes further and quotes Garrick as seeing Racine as an inhibitor of the actor's creativity. In 1767, to Mlle Jodin, he writes:

Garrick me disait un jour qu'il lui serait impossible de jouer un rôle de Racine, que ses vers ressemblaient à de grands serpents qui enlaçaient un acteur et le rendaient immobile; Garrick sentait bien et disait bien. ${ }^{24}$ 
The subject was obviously discussed in the winter of 1765 for Grimm makes a similar allusion to it in the Correspondance littéraire:

Il [Garrick] prétend que ce Racine, si beau, si enchanteur à lire, ne peut être joué, parce qu'il dit toujours tout, et qu'il ne laisse rien faire à l'acteur. ${ }^{25}$

- an indictment of Racine's dramatic efficacity from the pro-Shakespeare camp to which Voltaire would have reacted with characteristic venom!

The forceful image of the serpent recurs in the Paradoxe during a comparison of the English and French styles of acting and Garrick is once again personally quoted.

Despite this inability to play Racine, Garrick is seen by both Diderot and Grimm as possessing amazing versatility - a talent which allows him to be equally effective in both tragic and comic roles. Sterne, as we have seen, refers to this as a topic of discussion in 1762 and Grimm points to it again in 1765: "Il [Garrick] prétend qu'on ne saurait être bon acteur tragique sans être excellent acteur comique et je crois qu'il a raison." ${ }^{26}$ Diderot endorses the idea in the Paradoxe requiring his actor to have: "une égale aptitude à toutes sortes de caractères et de rôles, ${ }^{\prime 27}$ and once again, Garrick is the model:

Si vous lui demandiez, dis-je, la scène du Petit Garçon pâtissier, il vous la jouait; si vous lui demandiez tout de suite la scène d'Hamlet, il vous la jouait, également prêt à pleurer la chute de ses petits pâtés et à suivre dans l'air le chemin d'un poignard. ${ }^{28}$

Grimm had used the same example in 1765 although, unlike Diderot, he correctly identified the Shakespeare play in question as Macbeth and not Hamlet!

It would have been difficult to find a French actor or actress to exemplify such versatility. The French tradition was much less flexible, actors tending to be either "tragédiens" as in the case of Le Kain and Clairon or specialising in comic roles, like Préville. Grimm is singularly uncomplimentary with regard to Clairon's aptitude for comedy, stating that "elle n'a jamais su remplir un rôle comique, quel qu'il fût, d'une manière supportable." 29

Another element of Garrick's acting which particularly fascinated Diderot was his ability to assume a character. Grimm described it as:

la facilité de s'aliéner l'esprit et de se mettre dans la situation du personnage qu'il doit représenter; et lorsqu'il s'en est une fois pénétré, il cesse d'être Garrick, et il devient le personnage dont il est chargé. ${ }^{30}$ 
Between 1757 and 1770, Diderot examines and attempts to define this creative process. In the Entretiens, he sees the actor as effecting the transformation through what he describes as "sensibilité", an intuitive and emotional involvement of himself in a role. Intelligence and detachment are of secondary importance in the successful portrayal of a character. Dorval, in the Entretiens, affirms that:

... une actrice d'un jugement borné, d'une pénétration commune, mais d'une grande sensibilité, saisit sans peine une situation d'âme et trouve, sans y penser, l'accent qui convient à plusieurs sentiments différents qui se fondent ensemble, et qui constituent cette situation que toute la sagacité du philosophe n'analyserait pas. ${ }^{31}$

The actor or actress is not alone in this. Dorval includes all those involved in the creative arts:

Les poètes, les acteurs, les musiciens, les peintres, les chanteurs de premier ordre, les grand danseurs ... toute cette troupe enthousiaste et passionnée sent vivement, et réfléchit peu. ${ }^{32}$

Garrick, according to Diderot's theories of the late fifties, functions in the same manner, through an emotional involvement of himself in the role he is playing. Thus the question that Diderot poses to Mme Riccoboni after his account of Garrick's portrayal of the happy, then suddenly distraught father, is one to which he expects, at that time, (in 1758) a negative response:

Croyez-vous qu'alors Garrick songeait si on le voyait de face ou de côté; si son action était décente ou ne l'était pas, si son geste était compassé, ses mouvements cadencés? ${ }^{33}$

Unlike the self-conscious "mannequins" whose free expression is hampered by the conventions, Garrick, according to Diderot, totally involves himself in the role he is playing and is oblivious to all else.

By 1770, and after having personally observed Garrick's acting and discussed technique with him, Diderot has completely changed his mind. His theories have evolved to the extent that he rejects the emotionalist school of acting in a refutation of Sticoti's work Garrick et les acteurs anglais. Diderot's response to what Grimm calls "cette mauvaise brochure" is an article in the Correspondance littéraire for October 1770 entitled Observations sur une brochure intitulée 'Garrick et les acteurs an- 
glais' which was to be re-worked as Le Paradoxe sur le Comédien completed in 1773.

In a passage in which he takes issue with Sticoti's concept of the talented actor, Diderot states:

Au reste, je puis avoir tort, mais j'ai d'autres idées que l'auteur sur les qualités premières d'un grand acteur. Je lui veux beaucoup de jugement; je le veux spectateur froid et tranquille de la nature humaine; qu'il ait par conséquent beaucoup de finesse, mais nulle sensibilité, ou, ce qui est la même chose, l'art de tout imiter ... ${ }^{34}$

The same theory is developed throughout the Paradoxe. The truly inspired actor now maintains a total detachment and performs from studied imitation of nature. Although appearing to experience the emotion,

... il s'écoute au moment où il vous trouble, et ... tout son talent consiste non pas à sentir, comme vous le supposez, mais à rendre si scrupuleusement les signes extérieurs du sentiment, que vous vous y trompiez. ${ }^{35}$

Garrick is specifically evoked to exemplify this detachment:

Garrick passe sa tête entre les deux battants d'une porte, et, dans l'intervalle de quatre à cinq secondes, son visage passe successivement de la joie folle à la joie modérée, de cette joie à la tranquillité, de la tranquillité à la surprise, de la surprise à l'étonnement, de l'étonnement à la tristesse, de la tristesse à l'abattement, de l'abattement à l'effroi, de l'effroi à l'horreur, de l'horreur au désespoir, et remonte de ce dernier degré à celui d'où il était descendu. Est-ce que son âme a pu éprouver toutes ces sensations et exécuter, de concert avec son visage, cette espèce de gamme? Je n'en crois rien ... ${ }^{36}$

Diderot's response to the same question in 1758 would presumably have been an affirmative one. Now the actor can only perform such feats by maintaining a studied lack of personal involvement.

The image of Garrick with his head appearing in the doorway is an interesting one. A little-known water-colour sketch by Carmontelle, stored in the musée de Condé, depicts Garrick as described by Grimm in the Correspondance littéraire for July 1765:

M. de Carmontelle a dessiné Garrick en attitude tragique, et vis-à-vis de ce Garrick, il a placé un Garrick comique entre les deux battants d'une porte, 
qui surprend Garrick le tragique, et se moque de lui ... Pendant qu'il se faisait peindre, comme sa pétulance l'empêche d'être un moment tranquille, il s'exerçait à passer par des nuances imperceptibles de l'extrême joie â l'extrême tristesse, et jusqu'au désespoir et à l'effroi. Cela pourrait s'appeler la gamme du comédien. ${ }^{37}$

It is possible that Diderot attended one of these sittings but more likely that he embellished Grimm's description. What is important is that the author of the Paradoxe sees Garrick as demonstrating this amazing range of emotion with total detachment. (The Carmontelle portrait is also significant in that it depicts both the comic and the tragic Garrick drawing pictorial attention to the actor's versatility.)

Not only is Garrick's acting evoked in the paradoxe, his personal theories on his art are also quoted. In an effusive rhetorical address, Diderot calls upon him as witness:

Je te prends à témoin, Roscius anglais, célèbre Garrick, toi qui, du consentement unanime de toutes les nations subsistantes, passes pour le premier comédien qu'elles aient connu, rends hommage à la vérité! ${ }^{38}$

The "vérité" in question involves Garrick's assertion that he is not himself when portraying a character but that he plays from an ideal model conceived in his imagination:

Lorsque je t'objectai que ce n'était donc pas d'après toi que tu jouais, confesse ta réponse; ne m'avouas-tu pas que tu t'en gardais bien, et que tu ne paraissais si étonnant sur la scène, que parce que tu montrais sans cesse au spectacle un être d'imagination qui n'était pas toi? ${ }^{39}$

The passage echoes one in the Salon of 1767 in which Diderot quotes Garrick in a discussion with le chevalier de Chastellux, one of the 'habitués' of the salon d'Holbach. The idea of the imaginary being is again evoked and, to de Chastellux's question: 'Vous n'êtes donc jamais vous?" Garrick replies:

Je m'en garde bien. Ni moi, monsieur le chevalier, ni rien que je connaisse précisément autour de moi. Lorsque je $\mathrm{m}$ 'arrache les entrailles, lorsque je pousse des cris inhumains; ce ne sont pas mes entrailles, ce sont les cris d'un autre que j'ai conçu et qui n'existe pas. ${ }^{40}$

Thus, Diderot draws Garrick into the broader context of his esthetic inquiry into the process of the creative imagination and, in doing so, 
raises the actor to the level of poet, painter or sculptor as creative artist.

It is interesting to note that Suard, a mutual friend, left Garrick a rough draft of the Paradoxe in 1773 asking for the actor's comments. In February 1776 having received no response, he reminds him: "Vous m'aviez promis solemnellement de faire quelques notes au manuscrit de Diderot que je vous ai laissé en 1773."41 Garrick responds the following month: "As for the essay you left in my hands, by our friend, M. Diderot, you may depend upon my considering it well, and writing my remarks upon it." 42 No such manuscript has been found and it is likely that Garrick, by this time weary and frequently unwell, never in fact performed the service. Stone and Kahrl in their biography of the actor, suggest that Diderot himself sent the manuscript to Garrick. ${ }^{43}$ There appears to be no evidence of this but, given the glowing terms in which he refers to the actor, it is not inconceivable that Diderot intended to solicit Garrick's comments on it. A manuscript of the Paradoxe annotated by the actor would indeed make interesting reading.

The adulation of the Paradoxe is hardly surprising. Garrick was the incarnation of Diderot's own theories on the actor and his art: an innovator who relied greatly on mime, gesture and natural diction for dramatic effect, an actor of enormous versatility, an eager promoter of Shakespeare, a man of letters who sought the company of intellectuals and whose personal reputation brought dignity and respect to a much-maligned profession. But, above all, Garrick represented, for Diderot, the actor as creative artist on a par with poet, painter and writer and second to none in terms of the creative imagination. As Diderot himself states in the Paradoxe: "J'ai une haute idée du talent d'un grand comédien: cet homme est rare, aussi rare et peut-être plus que le grand poète." ${ }^{\prime 4}$

F.M. WILKSHIRE

Associate Professor

Memorial University 


\section{NOTES}

1. See Hedgcock, F.A., David Garrick and His French Friends, London, Stanley Paul \& Co., 1911, p. 108.

2. Collé, Charles, Journal et Mémoires, Paris, 1868, vol. I, p. 324

3. Sterne, Lawrence, Letters of Lawrence Sterne, Ed. by Lewis Perry Curtis, Oxford, Clarendon Press, 1935, p. 151.

4. Ibid.

5. Garrick, David, Letters of David Garrick, Ed. by Little and Kahrl, Harvard University Press, 1963, vol. I, p. 387.

6. Ibid., vol. II, p. 444.

7. Grimm, F.M., Correspondance littéraire, juillet 1765, ed. Tourneux, Paris, Garnier, 1978, p. 318.

8. Boaden, J., Private Correspondence of David Garrick, London, 1821, vol. II, p. 423.

9. Ibid., vol. II, p. 465.

10. Voltaire, Oeuvres Complètes, Paris, Garnier, 1877, vol. I, p. 314

11. Diderot, D., Oeuvres Esthétiques, ed. Paul Vernière, Paris, Garnier, 1968, pp. 100-101.

12. Ibid., p. 269.

13. Cited in Price, Cecil, Theatre in the Age of Garrick, Oxford, Blackwell, 1973, p. 31.

14. Collé, Charles, Journal et Mémoires, vol. I, p. 23.

15. Cited in Price, C., Theatre in the Age of Garrick, p. 14.

16. Lichtenberg, G., Vermischte Schriften, Gottingen, 1844, vol. III, pp. 209-10.

17. Cibber, Theophilus, Two Dissertations on the Theatres, (1756), p. 56.

18. Letters of David Garrick, Ed. Little and Kahrl, vol. I, p. 351.

19. Diderot, Oeuvres Esthétiques, pp. 101-2.

20. Diderot, Oeuvres Complètes, ed. Le Club Français du Livre, vol. III, p. 672.

21. Ibid., vol. III, p. 677.

22. Ibid.

23. Ibid., vol. V, p. 923.

24. Ibid., vol. VII, p. 477.

25. Grimm, F.M., Correspondance littéraire, vol. VI, p. 321.

26. Ibid., p. 319.

27. Diderot, Oeuvres Esthétiques, p. 306.

28. Ibid., p. 329.

29. Grimm, F.M., Correspondance littéraire, vol. VI, p. 319. 
30. Ibid., p. 318-19.

31. Diderot, Oeuvres Esthétiques, p. 104.

32. Ibid., p. 104.

33. Diderot, Oeuvres Complètes, vol. III, p. 677.

34. Ibid., vol. VIII, p. 637.

35. Diderot, Oeuvres Esthétiques, p. 312.

36. Ibid., p. 328.

37. Grimm, F.M., Correspondance littéraire, vol. VI, p. 319.

38. Diderot, Oeuvres Esthétiques, p. 346.

39. Ibid., p. 347.

40. Diderot, Oeuvres Complètes, vol. VII, pp. 42-3.

41. Boaden, J., Private Correspondence of David Garrick, vol. II, p. 623.

42. Letters of David Garrick, Ed., Little and Kahrl, vol. III, p. 1078.

43. Stone and Kahrl, David Garrick, A Critical Biography, Southern Illinois University Press, 1979, p. 307.

44. Diderot, Oeuvres Esthétiques, p. 347. 